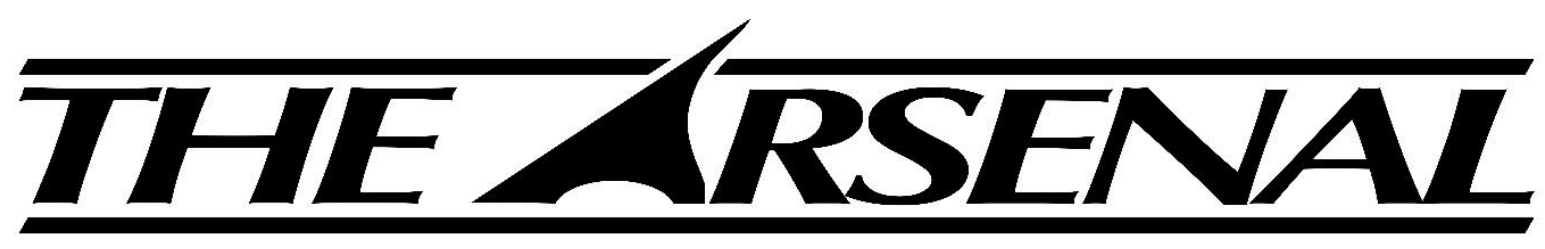
Augusta University's Undergraduate Research Journal

ISSN 2380-5064 | Arsenal is published by the Augusta University Libraries | http://guides.augusta.edu/arsenal

Volume 1, Issue 1 (2016)

Escape from a Life of Secrets and Emergence of

Psychopathy from a Mask of Sanity

Vattika Sivised

\title{
Citation
}

Sivised, V. (2016). Escape from a life of secrets and emergence of psychopathy from a mask of sanity. Arsenal: The undergraduate research journal of Augusta University, 1(1), 28-34. http://doi.org/10.21633/issn.2380.5064/f.2016.01.28 


\title{
Escape from a Life of Secrets and Emergence of Psychopathy from a Mask of Sanity
}

\author{
Vattika Sivised \\ Department of English \& Foreign Languages \\ Pamplin College of Arts, Humanities, and Social Studies \\ Faculty Mentor: Todd Hoffman, Ph.D., Department of English and Foreign Languages
}

This paper explores the progression of psychopathy within the main character of Jim Thompson's The Killer Inside Me. Lou Ford hides behind a social mask depicting a kindhearted oaf to conceal the psychopathic and violent personality that lies beneath. Throughout the novel, Lou Ford's psychopathic personality begins to surface as he progresses from mere verbal jabs to murder as he tries to escape from his past and his obligations to his father. These obligations that he has put upon himself keep him from leaving the town; however, as he destroys the chains that bind him to the town by murdering those who represents these chains, his psychopathic personality, which is his real personality, grows in strength, and soon, the truth of his violent nature is known by the rest of the characters. In the end, to truly escape from the town, Lou Ford commits his final act: suicide. This act of suicide frees him from the past and he was able to be who he always was, a psychopath.

Received: 02/02/2016 Accepted: 06/01/2016

Correspondence: Vattika Sivised, Augusta University, $112015^{\text {th }}$ St. Augusta, GA 30912, vsivised@augusta.edu 


\section{ESCAPE FROM A LIFE}

When the term "escape" comes up in either private thoughts or public conversations, one may assume that the word is used to describe the act of running away from someone or thing. The idea of escape is seen in various films and novels; in those types of plots, the idea is usually centered on the protagonist either running away from an antagonist, devising some scheme to get out of a sticky situation, or some other plotline along the lines of the aforementioned. In the novel, The Killer Inside Me by Jim Thompson, the idea of escape is used to portray the destruction of the connections linking the main character, Lou Ford, to his past, revealing a slow emergence of his hidden psychopathic side. This psychopathy manifests through Lou's increasing sadistic behavior, perpetuated against his victims before and during his murder of them as his need to escape his past increases. Specific examples of this dramatic behavior include the brutality shown in the sexual relationships he creates with two of his victims and the method of killing he employs, one of which involved strangling a person with a belt. Lou Ford's psychopathy is further characterized by a desperate need to escape from his condition, one that has been created through perceived obligations to his father.

Lou's first struggle to escape his current situation is between the fantasy world that is his constructed public persona and the reality of his cruel psychopathic persona. For most individuals, whether they are psychopathic or not, putting on public masks seem to be appropriate in most situations and a majority find themselves relying on these public masks more often than others. A public mask allows individuals to stick to what society deems appropriate while masking any inappropriate thoughts they may truly possess. According to Perri (2011), "... [Psychopaths] cold-bloodedly take what they want and do as they please, violating social norms and expectations without the slightest sense of guilt or regret" (p. 45). For psychopathic individuals, these façades allow them to interact with society without revealing deeper, disturbed sides that would go against societal norms; an example of which would be an intense act of violence, such as murder, that society would reject without hesitation. For Lou Ford, his mask is that of a kindhearted, bumbling idiot who constantly utters moral phrases to anyone; he has created a façade that presents himself as a man who others are unable to walk away from without appearing rude. This public mask hides Lou's darker persona: A violent, sadistic psychopath who enjoys tormenting others out of whimsy. According to Moreira Almedia, Ointo, and Fáveroet (2014), "[...] primary psychopaths are characterized by impulsive, aggressive, hostile, extrovert traits." According to Clark (2009), "Lou has constructed a persona that enables him to carry on his police duties and be a member of his community. It is a persona meant to fool his neighbors, to keep them from knowing the truth about him" (p. 52). The mask allows Lou to maneuver through his 
daily life as a happy-go-lucky sheriff without drawing suspicions from his fellow town's folks to his psychopathic side. This psychopathic side mainly reveals itself in his abusive sexual relationships.

For Lou Ford, the public mask that he wears represents a fantasy world wherein he is unable to be himself while the inner cruelty that lies within him represents the reality of his personality that he hides from the public. When in the privacy of his father's study, Lou feels as if "[it] was like coming out of the darkness and into the sunlight, out of a storm into the calm. Like being lost and found again" (Thompson, 2014, p. 25). The text suggests that as long as Lou hides away his true psychotic self with his public mask, he will feel as if a crucial part of him is missing. Because of his environment, Lou is unable to show his cruel nature, and only when hidden away from the outside world does he feel whole.

To Lou, his father's study is implied to be a haven, one where he does not have to put up a front. "All the answers were here, out in the open where you could look at them. And no one was terrified or horrified. [He] came out of the place [he] was hiding in - that [he] always had to hide in-and began to breath" (Thompson, 2014, p. 25).

These sentences suggest that Lou acknowledges and accepts that he is the way he is as he is only able to relax when he removes all the pretenses of being kind. The study is where his father keeps his medical books, and it is the place where Lou overhears his father arguing with the housekeeper about Lou's secret affair with her. This implies that the room is a place where the truth of his cruelty is revealed and does not need to be hidden. The room is where reality does not give way to fantasy. Found within the room later in the novel is a picture of Helene in an inappropriate position. According to Miller (2014), possible future serial killers "[nurture] sadistic sexual fantasies, sometimes accompanied by transvestism, voyeurism, exhibitionism, and other fetishes, usually involving violent pornography" (p. 13). This picture is implied to be one of the items that represents the first glimpse his father gets of Lou's growing sadistic psychopathic side. The medical books are suggested to represent the cold hard facts that is not hidden behind pretty words that can lead a person astray from the truth. In this room, Lou's psychopathic side is given free reign, one that is not covered up by a public mask.

Outside of his private haven, Lou wears the public mask to fit in with his surroundings to appear normal in front of the townspeople; however, the novel implies that, although he is unable to truly express his cruelty in all its violent glory, Lou manages to take out his sadistic pleasures in a more sated version. This version comes in the form of awkward moral phrases that he throws out in various conversations and other points in the novel. According to Clark (2009), "Lou shows his hand in his perverse 
presentation of what is his persona's signature trait: the utterance of skeins of platitudes ... Lou reveals that he uses this character trait sadistically to toy with and torture others" (p. 53). "[He] began needling people in that dead-pan way-needling [them] as a substitute for something else" (Thompson, 2014, p. 12). This examination of the text and the implications within the novel itself suggests that since Lou is unable to be as cruel as he wants to in public, he is willing to resort to these jabs to make people squirm for his own sadistic enjoyment. To Lou, "striking at people that way is almost as good as the other, the real way" (Thompson, 2014, p. 5). "He intentionally bores his neighbors as an act of veiled violence: language is a weapon of his" (Clark, 2009, p. 53). The ability to cause discomfort in others appeases his psychotic side, and this enjoyment gives a glimpse past the fantasy persona and into the real sadistic personality of Lou Ford.

Along with his uncomfortable moral phrases, Lou reveals one way he attempts to escape from the confines that binds him to have a public persona instead of showing his true character to the world: secret abusive relationships. His abusive relationships with Amy Stanton and Joyce Lakeland is a method that he uses to escape from the fantasy that is his kindhearted public persona while fueling his psychopathic tendencies. In both relationships, Lou does not need to hold back his sadistic side like he has to in his everyday life. Instead, he can lose control and give himself completely to his psychotic side, and the longer he has the relationship, the more sadistic he becomes as he gets comfortable with being himself again. The text suggest that Lou does like to be able to embrace his sadistic traits when he is unable to forget about Joyce. Compared to Amy, Lou is more abusive with Joyce since she is a prostitute with no real connection to the town. When she is no longer within his grasp, Lou appears to miss the moments he has with her in which he is able to embrace the reality that he is a psychopath. This can be seen when he tells Joyce that "I'm going to miss you, baby ... You've got to go, but I'm sure going to miss you" (Thompson, 2014, p. 44). Even though Lou knows that he needs to eliminate Joyce as she is a threat to his public persona, the text implies that he will miss one of the only opportunities that he has to be himself and to go about being abusive and sadistic without being reprimanded for it.

His second struggle with escape comes in the form of his victims and how each connects him to the town and his past. The novel implies that through some form of obligation to his father and his brother, Lou is unable to leave the town behind and remains trapped with his public persona that his father suggests he creates to appear normal to the townspeople even though Lou suffers from psychopathy. According to Laurence Miller (2014), psychopathic killers' "fantasized fusing of cruelty and sexuality usually begins in adolescence, sometimes in childhood, and develops over their lifespan." Lou's sadistic psychopathic side stems from his adolescent years with an 
abusive sexual affair with his father's housekeeper Helene and gradually increases until it leads him to the incident where he sexually abuses a child, leading to him feeling indebted to his father and brother. "Lou suppresses the 'sickness,' never leaves town despite his lineage and intelligence, and becomes a deputy sheriff. To hide the sickness of the true Lou-the killer inside him-he constructs the persona of the stereotypical small town peace officer" (Clark, 2009, p. 55). The text suggests that after his father has Mike, his adopted brother, take the blame for Lou's sexual harassment of a child, Lou feels obligated to suppress his psychopathic side and stay in the town like his father wanted him to after finding out about Lou's psychopathy. Through Clark's interpretation and with what the text implies, Lou feels indebted to him, and as the plot progresses, his desire to escape from this obligation leads him to kill off the victims that connects him to his past.

Lou's first victim that appears in the novel suggests the beginning of his attempt to escape from his past. According to Perri (2011), "most psychopaths are mentally capable of appreciating the criminality of their actions and can be rather methodical and strategic regarding their crimes" (p. 44). For Lou, killing is a way to sever his ties with his past, and he tries to plan out each killing before actually proceeding through with the act to shift suspicion away from himself. Through his planning, he is able to kill a good number of people who connect him to his past and the town:

"Joyce and Elmer were going to die. Joyce had asked for it. The Conways had asked for it. I wasn't any more cold-blooded than the dame who'd have me in hell to get her own way. I wasn't any more cold-blooded than the guy who'd had Mike knocked from an eight-story building" (Thompson, 2014, p. 41).

He kills Elmer Conway because the text implies that Elmer's father has someone murder Mike. Because Mike takes the blame for Lou's mistake in the past with the sexual harassment, Lou feels obligated to seek out revenge against the person who orders Mike's murder. By killing Elmer Conway, Lou no longer has to feel like he is indebted to Mike for saving him back then with the child and he is now able to move on with his life. By killing Joyce, Lou is eliminating a possible threat to his goal of escaping the town as she tells Lou that "I wouldn't want to ..., but I'm not going to give you up. Never, never, never. If you're too good for me now, then I'll make it so you won't be'" (Thompson, 2014, p. 13). The text suggests that Joyce is not going to willingly let Lou go without the threat of tearing apart his life and revealing his psychopathic side to the world, and thus, Lou feels like he needs to get rid of her to protect himself. By killing the rest of his victims with the exception of the bum, he is implied to be severing his ties to the town as Amy is meant to marry him while Johnny is a boy that he helps out from time to time. 
Another reason he may have tried to kill both Joyce and Amy is because of their implied connection to the housekeeper that Lou has an affair with when he was younger. In Lou's eyes after finding the picture of Helene in his father's study, he appears to see "how much [Helene] looked like Joyce. How there was even a strong resemblance between her and Amy Stanton" (Thompson, 2014, p. 101). The text implies that because the two women resemble Helene that Lou saw Helene within Amy and Joyce, thus killing them to try and get back at Helene. According to Simons (2001), "mission-oriented sadistic killers may also focus on victims who are merely substitutes for the intended, but unavailable target" (p. 349). This can imply that since Helene, the housekeeper, threatened to expose Lou in the past and thereby ruin his father's name, Lou feels obligated to destroy those who resemble the person who has caused him pain in his past. By killing Amy and attempting to kill Joyce, he is attacking the cause of his father's and his own past frustrations, and by succeeding in his second kill, he is able to chip away at his obligations to his father little by little in his attempt to escape from his current confines.

Lou's third and final struggle with escape comes at the end of the novel when he finally reaches the conclusion that the only way to escape from the cage he lives in is to take his own life. The first sign that suggests Lou is escaping from his obligations is when he meets Joyce for the first time and his sadistic side resurfaces after having been buried for so long under his public persona. During the confrontation, he explains that "I tried to push past her. I had to get out of there. I knew what was going to happen if I didn't get out, and I knew I couldn't let it happen. I might kill her. It might bring the sickness back" (Thompson, 2014, p. 10). Lou is having an internal struggle with himself as his real personality is trying to break free of the chains that try to hold it back because of the obligations he has to his father in trying to be a normal person and fitting in with society. In the end of this struggle, Lou's real self comes to light as he sadistically beats Joyce, signaling the start of his own internal escape from the public mask he wears. The more he tries to resist and restrain his true nature, the harder it is to hide his cruel personality until finally the truth is revealed and his psychopathic side is allowed to run free as he tries to escape from the town by severing his connections to the townspeople.

Even with all his attempts to get away from his past, Lou realizes that he is unable to escape now that he is caught. The only way for him to truly escape from the confines of the town and his past, the last possible option, is to commit suicide. He even goes on to say that "I couldn't have gone, no matter how things were. It's like you say, $I^{\prime} m$ tied here. I'll never be free as long as I live" (Thompson, 2014, p. 223). This implies that no matter what Lou does, there will always be some connection that remains that 
will keep him from truly moving on and away from the town. To solve this problem, he douses the entire interior of the house with oil and burns down the house in the implied explosion at the end of the novel. By doing this, Lou is finally able to erase all traces of his past, thus truly destroying his connection to the town and his father. He is finally able to move on from being bound into a fantasy role of someone who is sane and kindhearted to someone who is free from all chains now that he is dead.

In the end, Lou is able to obtain what he desires most: An escape from the town and his past. Though it is slow and gradual, Lou reveals his progressive escape from the town through his growing psychopathic tendencies from verbal jabs to murder. As his actions escalate in coldness and violence, he comes closer and closer to true escape until finally he achieves it by way of suicide. He kills victims, such as Joyce and Elmer Conway, who remind him of the past and keep him connected to the town even though they may not know it. This connection stems from his perceived obligation to his father. His interactions with the other characters, especially in those abusive sexual relationships, helps his psychopathic side grow in intensity. Each escalation brings him closer to reality, which is his true self, and further away from the fantasy of being sane and normal like everyone else in society, an image that his father wishes for him to maintain. Lou Ford hides his real side from the other characters throughout the novel, and is only able to achieve his escape once the real side comes to light and his connections to his past and his obligations to his father are completely severed.

\section{REFERENCES}

Clark, D. G. (2009). Being's wound: (Un)explaining evil in Jim Thompson's The Killer Inside Me. Journal of Popular Culture, 42(1), 49-66.

Miller, L. (2014). Serial killers: II. Development, dynamics, and forensics. Aggression and Violent Behavior, 19(1), 12-22.

Moreira, D., Almeida, F., Pinto, M., \& Fávero, M. (2014). Psychopathy: A comprehensive review of its assessment and intervention. Aggression and Violent Behavior, 19(3), 191-195.

Perri, F. S. (2011). The flawed interview of a psychopathic killer: What went wrong? Journal of Investigative Psychology \& Offender Profiling, 8(1), 41-57.

Simons, C. L. (2001). Antisocial personality disorder in serial killers: The thrill of the kill. Justice Professional, 14(4), p. 345.

Thompson, J. (2014). The killer inside me. New York: Hachette Book Group, Inc. 